\title{
Narodowy Instytut Onkologii i Hematologii im. Marii Skłodowskiej-Curie - być albo nie być?
}

\author{
National Institute of Oncology and Hematology — to be or not to be?
}

\author{
Krzysztof Warzocha
}

Klinika Hematologii, Instytut Hematologii i Transfuzjologii, Warszawa

\section{Streszczenie}

1 stycznia 2016 roku miat być pierwszym dniem funkcjonowania Narodowego Instytutu Onkologii i Hematologii im. Marii Sktodowskiej-Curie (NIOH), powstatego z potaczenia Centrum Onkologii - Instytutu (CO-I) z Instytutem Hematologii i Transfuzjologii (IHT). Projekt rozporzqdzenia Rady Ministrów (KRM-110-101-15) w tej sprawie zostat opublikowany przez Rzqdowe Centrum Legislacji $i$ po konsultacjach publicznych, przeprowadzonych $w$ dniach 13-20 października 2015 roku, zostat przekazany przez ministra zdrowia do Statego Komitetu Rady Ministrów w celu podpisania projektu rozporzadzenia przez Prezesa Rady Ministrów. Bez podania przyczyny przedmiotowy proces legislacyjny zostat nagle wstrzymany. Ówczesny Minister Zdrowia - Marian Zembala - nie poinformowat o takim zamiarze Rad Naukowych ani dyrektora obu taczonych instytutów. $Z$ docierajacych informacji medialnych wydaje się, ze na takiej decyzji zawazyta prowadzona $w$ tym samym czasie $z$ inicjatywy ministra zdrowia, jednak z pominieciem przepisów prawa i bez zgody dyrektora oraz bez opinii Rady Naukowej CO-I, próba wydzielenia z CO-I majątku należacego do oddziatu w Gliwicach, co uniemożliwito dokończenie procesu konsolidacji instytutów ze względu na brak tożsamości wniosków, opinii, uchwat, dokumentów, a przede wszystkim podmiotów, które byty przedmiotem analizy i postepowania przygotowawczego $w$ tej sprawie. W konsekwencji tych dziatań zaprzepaszczono wysitki obu instytutów oraz koszty wtożone w przygotowanie procesu unifikacji. Pozytywne skutki programu naprawczego realizowanego $w$ CO-I w latach 2012-2015, który zostat zlecony przez ministra zdrowia oraz Najwyzsza Izbe Kontroli po negatywnej ocenie jego funkcjonowania $w$ poprzednich latach, takze staty sie zagrożone. Ta podjęta ze szkoda dla interesu publicznego decyzja zahamuje dalszy rozwój CO-I oraz IHT i będzie stanowita zagrożenie dla kontynuowania ich działalności $w$ dotychczasowej formie organizacyjno-prawnej, a także narazi Skarb Państwa na dodatkowe obciażenia w przysztości. Niniejsze opracowanie stuży udokumentowaniu kilkuletnich dziatań podejmowanych przez Pracowników Ministerstwa Zdrowia, CO-I oraz IHT $w$ celu utworzenia NIOH. Być może będzie pomocne decydentom w przysztości. Nie ulega bowiem watpliwości, że wzmocnienie potencjatu badawczego, naukowego, edukacyjnego, diagnostycznego i leczniczego obu instytutów poprzez ich konsolidacje miatoby istotne znaczenie dla dalszego rozwoju polskiej onkologii, hematologii i transfuzjologii. Nie ulega także watpliwości, że utworzenie NIOH o statusie Państwowego Instytutu Badawczego - podlegtego bezpośrednio ministrowi zdrowia - zajmujacego sie w sposób kompleksowy świadczeniami diagnostyczno-leczniczymi u chorych na wszystkie rodzaje nowotworów, a także ksztatceniem podyplomowym

Adres do korespondencji: Krzysztof Warzocha, Klinika Hematologii, Instytut Hematologii i Transfuzjologii, ul. Indiry Gandhi 14, 02-776 Warszawa, e-mail: warzocha@ihit.waw.pl 
i badaniami naukowymi w tytutowych dziedzinach, ma gtęboki i ponadczasowy sens oraz uzasadnienie merytoryczne, prawne, organizacyjne i finansowe.

Słowa kluczowe: Narodowy Instytut Onkologii i Hematologii, Centrum Onkologii — Instytut, Instytut Hematologii i Transfuzjologii, Połączenie, Państwowy Instytut Badawczy

Hematologia 2015; 6, 4: 313-408

\section{Abstract}

January 1, 2016 was scheduled for being the operational launch date of the new Maria Sklodowska-Curie Memorial National - Institute of Oncology and Hematology (NIOH), arising from a merger between the Centre for Oncology - Institute (CO-I) with the Institute of Hematology and Transfusion Medicine (IHT). A Council of Ministers' draft regulation (KRM-110-101-15) had already been published on this matter by the Government Legislative Centre. Following a public hearing held on 13-20 October 2015, this draft was then passed by the Ministry of Health to the Standing Committee of the Council of Ministers for the purpose of being signed by the Prime Minister. For no given reason whatsoever, this legislative process was however abruptly halted; then Minister of Health, Marian Zembala, having chosen not to inform his decision to either the Management Boards or the joint Director of these merging institutions. According to media reporting, it appears this was an attempt to circumvent legally binding regulations by setting aside real estate belonging to the CO-I at the Gliwice branch, due to the decision taken by the Minister of Health without the consent of the institutes' joint Director nor Management Boards. This prevented consolidating the merger, because of differences still existing in the merger applications, opinions, documentation, resolutions and most importantly in the merging parties themselves which were then being resolved. As a result of such actions, the long-term efforts in organising and financing the harmonisation of administrative and management procedures of the merger at both institutions has been wasted. The beneficial outcomes of the recovery programme implemented at the CO-I from 2012-2015 may have also been squandered; this having been commissioned by the Ministry of Health and the Supreme Chamber of Control, due to an adverse assessment of the CO-I made in previous years. This confusing and socially divisive decision to the public good will thus arrest the further development of the CO-I and IHT, and indeed threaten their continuing to operate in their existing organisational and legal forms; it will also expose the National Treasury to additional future burdens. The presented study serves to document several years of actions undertaken by the Ministry of Health, CO-I and IHT for establishing NIOH. Perhaps it can help guide decision-makers in the future. Undoubtedly, strengthening the capacity for undertaking research, science, education, diagnostics and treatment in both institutes through their consolidation, will be crucial for their developing vital and complementary areas of medicine, namely oncology, hematology and transfusion medicine. Beyond question, establishing NIOH with a status of the Public Research Institute - directly subordinated to the Ministry of Health - for delivering comprehensive diagnostic and therapeutic services, together with providing a centre of excellence for post-graduate education and reseach will have a profound and lasting benefit to patients suffering from all types of malignancies as well as being justified in terms of the professional, legal, operational and financial advantages so conferred.

Key words: National Institute of Oncology and Hematology, Centre for Oncology — Institute, Institute of Hematology and Transfusion Medicine, Connection, Public Research Institute

Hematologia 2015; 6, 4: 313-408 


\section{Wprowadzenie}

W 2011 roku Najwyższa Izba Kontroli (NIK) przeprowadziła kompleksową kontrolę funkcjonowania wybranych instytutów badawczych podległych ministrowi zdrowia (KPZ-4101-05/2011), ze szczególnym uwzględnieniem skali prowadzonych przez nie badań naukowych i prac rozwojowych oraz nadzór sprawowany przez ministra zdrowia nad tymi jednostkami [1]. Cele szczegółowe tej kontroli obejmowały ocenę:

- zakresu i efektów projektów badawczo-rozwojowych realizowanych przez instytuty;

- sytuacji ekonomiczno-finansowej instytutów;

- organizacji działalności instytutów w systemie ochrony zdrowia;

- sposobu i zakresu nadzoru sprawowanego przez ministra zdrowia nad działalnością instytutów badawczych.

Do kontroli dobrano jednostki o największym zadłużeniu, w tym Centrum Onkologii - Instytut (CO-I) w Warszawie. Kontrola objęła okres od 1 stycznia 2008 roku do połowy 2011 roku. Najwyższa Izba Kontroli negatywnie oceniła funkcjonowanie skontrolowanych instytutów, przede wszystkim $z$ powodu niezadowalającej skali realizacji zadań ustawowych przez te jednostki oraz złej kondycji finansowej. W ocenie NIK powyższe zaniedbania stanowiły poważne zagrożenie dla kontynuowania działalności niektórych instytutów w dotychczasowej formie organizacyjno-prawnej, w tym dla CO-I. Podkreślono, że mimo wielokrotnych zapewnień w przeszłości nie zrealizowano w nich podstawowych działań naprawczych i przedsięwzięć restrukturyzacyjnych.

W odniesieniu do CO-I stwierdzono przede wszystkim [1]:

- narastanie w latach 2008-2011 strat w działalności podstawowej w kwocie około $65 \mathrm{mln}$ zł. W tym samym okresie wysoki poziom osiągnęły zobowiązania wymagalne, w kwocie ponad $230 \mathrm{mln}$ zł. W 2010 roku nastąpił spadek wysokości zobowiązań wymagalnych w wyniku zamiany zobowiązań krótkoterminowych na długoterminowe w wyniku zawarcia porozumień $z$ wierzycielami wtórnymi na łączną kwotę ponad $97 \mathrm{mln}$ zł. Operacja ta poprawiła bieżącą sytuację jednostki, nie rozwiązała jednak problemów systemowych, które stanowity przyczynę trudności finansowych CO-I;

- niepodjęcie działań w zakresie restrukturyzacji zatrudnienia, które w przedmiotowym okresie zwiększyło się w CO-I o około 200 nowych etatów;
- niewprowadzenie motywacyjnego systemu wynagradzania;

- brak kompleksowego systemu informatycznego, które dostarczałoby precyzyjnej informacji zarządczej;

- wadliwość systemu raportowania do Narodowego Fundusz Zdrowia (NFZ) o wykonanych świadczeniach;

- brak przejrzystych i korzystnych dla CO-I zasad prowadzenia badań klinicznych;

- nieprawidłowości w zakresie realizacji umów zawartych $z$ NFZ, które miały niekorzystne skutki finansowe dla CO-I;

- wypłacanie bardzo wysokich nagród pracownikom i dyrekcji instytutu, których wysokość nie była uzależniona od sytuacji ekonomiczno-finansowej CO-I;

- nieprawidłowości w realizacji umów cywilnoprawnych, polegających między innymi na nieprowadzeniu ewidencji czasu pracy, w którym była wykonywana umowa zlecenie, oraz nieokreślanie jej zakresu w odniesieniu do zgodności z kartą charakterystyki stanowiska pracy, co prowadziło do zawierania umów na realizację zadań, które należały do obowiązków służbowych pracowników;

- niewystarczającą skalę prac badawczo-rozwojowych i wysokość uzyskiwanych w związku z tym przychodów przez CO-I;

- niewywiązywanie się Rady Naukowej CO-I $z$ obowiązku ustawowego nakazującego jej opiniowanie rocznych sprawozdań dyrektora $z$ wykonanych zadań;

- błędy w dokumentacji lekarskiej i w postępowaniach konkursowych na wyłanianie wykonawców do realizacji świadczeń zleconych oraz w prowadzeniu ksiagg rachunkowych CO-I. Najwyższa Izba Kontroli negatywnie oceniła także działalność ministra zdrowia w zakresie nadzoru sprawowanego nad instytutami badawczymi. Szczególnie krytycznie, pod względem celowości i rzetelności, oceniono bierność ministra w zakresie działań zmierzających do zmiany organizacji funkcjonowania podległych sobie jednostek oraz monitorowania podejmowanych przez nie działań naprawczych.

Mając na uwadze potrzebę lepszego wykorzystania potencjału naukowego instytutów, a także racjonalność gospodarowania środkami finansowymi oraz majątkiem instytutów, NIK przedstawiła następujące wnioski pokontrolne pod adresem ministra zdrowia [2]:

- rozważenie celowości dalszego funkcjonowania, w obecnej formie organizacyjno-prawnej, tych jednostek, które charakteryzują się 
najniższą aktywnością w prowadzeniu badań naukowych;

- ewentualne zmniejszenie liczby instytutów, co powinno się łączyć ze wzmocnieniem potencjału badawczego jednostek, których działalność ma kluczowe znaczenie dla rozwoju nauk medycznych;

- podjęcie działań, w ramach sprawowanego nadzoru, w celu szybkiego wdrożenia rozwiązań zapobiegających dalszemu zadłużaniu się instytutów;

- dokonanie analizy przyczyn niskiego udziału aparatury naukowo-badawczej w majątku instytutów w celu przyjęcia rozwiązań, które stymulowałyby aktywność dyrektorów poszczególnych instytutów w celu pozyskania środków, także pozabudżetowych, na zakup tego rodzaju aparatury;

- uwzględnianie, przy dokonywaniu ocen pracy dyrektorów instytutów, aktywności w prowadzeniu badań naukowych i wdrażaniu wyników badań podstawowych do praktyki klinicznej;

- zaangażowanie Rady Naukowej przy ministrze zdrowia w tworzenie rozwiązań zmierzających do poprawy efektywności funkcjonowania instytutów i zwiększenia ich aktywności w zakresie działalności naukowo-badawczej.

Ponadto szczegółowe zalecenia pokontrolne NIK wobec CO-I obejmowały [3]:

- intensyfikację działań restrukturyzacyjnych, $\mathrm{w}$ tym dotyczących zatrudnienia;

- prowadzenie rozwiązań zapewniających powiązanie efektów ekonomicznych komórki organizacyjnej z poziomem wynagradzania pracowników CO-I;

- zwiększenie nadzoru nad realizacją umów cywilnoprawnych, kontraktu $z$ NFZ i postępowań konkursowych prowadzonych przez CO-I;

- zwiększenie przychodów instytutu wynikających $\mathrm{z}$ realizacji prac badawczych;

- zwiększenie nadzoru na służbami finansowo-księgowymi w celu zminimalizowania ryzyka wystąpienia nieprawidłowości.

\section{Określenie potrzeby i warunków reorganizacji CO-I}

W wyniku wystąpień pokontrolnych NIK ówczesna Minister Zdrowia, Pani Ewa Kopacz, zarządzeniem z 19 października 2011 roku, powołała zespół roboczy do przeprowadzenia postępowania przygotowawczego mającego na celu ocenę potrzeby i warunków reorganizacji CO-I [4]. Zespołowi przewodniczył Podsekretarz Stanu w Minister- stwie Zdrowia (MZ), Pan Andrzej Włodarczyk. Do tego zespołu należeli między innym: profesorowie Marek Nowacki, Marian Reinfuss, Bogusław Maciejewski, Kazimierz Roszkowski-Śliż, Andrzej Hellmann, Jerzy Stelmachów, Leszek Królicki, Jacek Jassem, Krzysztof Warzocha, mgr Witold Kmiotek oraz przedstawiciele Ministerstwa Nauki i Szkolnictwa Wyższego (MNiSW) i departamentów MZ, w tym Nauki i Szkolnictwa Wyższego, Polityki Zdrowotnej, Budżetu, Finansów i Inwestycji, Nadzoru, Kontroli i Skarg oraz Organizacji Ochrony Zdrowia. Zespół roboczy był zobowiązany przedłożyć ministrowi zdrowia swoją opinię w terminie 3 miesięcy.

W styczniu 2012 roku taka opinia — „Projekt koncepcji działań zmierzających do naprawy sytuacji w Centrum Onkologii - Instytucie" - powstała. Stwierdzono w niej między innymi, że „(...) istniejąca sytuacja we wszystkich obszarach działania CO-I wymaga niezwłocznego przeprowadzenia gruntownych zmian wraz z sukcesywnie realizowanym programem naprawy (...). Należy rozważyć koncepcję połączenia CO-I z IHT, co skutkować będzie stworzeniem nowej osoby prawnej”. Zespół zwrócił uwagę na pewne zagrożenia dla realizacji takiej koncepcji, w tym zwłaszcza na „problem uregulowania zobowiązań finansowych leżących po stronie CO-I".

W konkluzji opinii zespołu roboczego napisano: „W świetle przytoczonych rozważań wydaje się słuszne zaproponowanie rozwiązań stosowanych $\mathrm{w}$ innych krajach, o których była mowa w propozycji prof. Krzysztofa Warzochy, co zawiera koncepcję Narodowego Instytutu Nowotworów prezentowaną przez prof. Mariana Reinfussa, przedłożoną pracującemu od kilku miesięcy zespołowi przygotowującemu kierunek zmian w obrębie działań związanych $z$ onkologią. $Z$ ww. przedłożeń jawi się jednostka wiodąco-koordynująca (np. Narodowy Instytut Nowotworów w USA, Kompleksowe Centrum Onkologiczne w Holandii), która stanowi nadbudowę sieci onkologicznej działającej zarówno w obszarze nauki, kształcenia podyplomowego, jak i świadczeń zdrowotnych".

\section{Cele programu naprawczego w $\mathrm{CO}-\mathrm{I}$}

Wskutek zaleceń pokontrolnych NIK oraz opinii przedstawionej przez zespół roboczy do oceny potrzeby i warunków reorganizacji CO-I cele postawione kandydatowi na stanowisko dyrektora instytutu przez ministra zdrowia w 2011 roku były jasne i wynikały $z$ analizy ówczesnych problemów instytutu. $Z$ powodu wieloletnich zaniedbań orga- 
nizacyjnych instytut utracił płynność finansową. Ta sytuacja była spowodowana przede wszystkim przyczynami wewnętrznymi, gdyż zmniejszeniu sprzedaży usług medycznych towarzyszyły jednocześnie niskie obłożenie łóżek szpitalnych (ok. 50\%) i wielomiesięczne kolejki chorych do ambulatorium i hospitalizacji. $Z$ roku na rok kontrakt CO-I z NFZ się zmniejszał, co wynikało $z$ jego niewykorzystania $w$ poprzednich okresach rozliczeniowych, a „zaoszczędzone” w ten sposób przez Mazowiecki Oddział Wojewódzki NFZ środki finansowe przekazywano do innych, w tym nowopowstających, podmiotów świadczących usługi onkologiczne w regionie. Co gorsza, ośrodki te zaczęły „podkupywać” wykształconą kadrę specjalistów z CO-I, co na zasadzie „błędnego koła” pogarszało trudną sytuację instytutu. Konwersja długu przeprowadzona w 2010 roku — poprzez przekazanie zadłużenia do wierzycieli wtórnych - tylko doraźne poprawiła sytuację, $\mathrm{i}$ to jedynie $\mathrm{w}$ wymiarze finansowym, ponieważ w rzeczywistości, bez jednoczesnego wdrażania działań naprawczych, mechanizm ten nie usunął przyczyny problemów, a dodatkowo wytworzył „kotwicę" zadłużenia w postaci narastającego zobowiązania finansowego wynikającego $z$ obsługi „odsprzedanych długów” szpitalnych (w wymiarze kilkunastu $\mathrm{mln} \mathrm{zl} /$ rok).

Ponadto odnotowano stałe, coroczne zmniejszenie wykorzystania łóżek szpitalnych i konsekwentnie malała liczba przyjmowanych chorych w ramach hospitalizacji (ok. 2 tys. mniej przyjmowanych chorych rocznie). Wykorzystanie bloku operacyjnego nie przekraczało $70 \%$ posiadanego potencjału infrastrukturalnego i kadrowego. Średni czas oczekiwania pacjenta na przyjęcie na oddział szpitalny wydłużał się i zwykle przekraczał 5 tygodni. Przychody $z$ tytułu głównego źródła finansowania, jakim była realizacja kontraktu $z$ NFZ, zmniejszały się, co w konsekwencji wpłynęło negatywnie na płynność finansową instytutu — zadłużenie na koniec 2011 roku przekroczyło $135 \mathrm{mln}$ zł.

Poza problemami organizacyjnymi i finansowymi obserwowano brak należytego nadzoru nad efektywną realizacją i sprawozdawczością świadczeń zdrowotnych do NFZ w poszczególnych klinikach, zakładach, poradniach i innych komórkach organizacyjnych instytutu. Brakowało właściwej metody rozliczania kosztów poszczególnych komórek organizacyjnych oraz metody kalkulacji kosztów badań diagnostycznych. Nie monitorowano efektywności czasu pracy dla zakładów i pracowni diagnostycznych. Na wszystkie wyżej wymienione negatywne zjawiska nakładał się brak motywacyjnego systemu wynagradzania pracowników CO-I, a w rankingu aktywności naukowej prowadzonej przez MNiSW instytut sklasyfikowano do kategorii $\mathrm{C}$ i z tego względu nie mógł liczyć na wysokość dotacji pokrywającej choćby koszty zatrudnienia pracowników naukowych, nie wspominając już o realizacji badań naukowych. Te ostatnie finansowano $z$ innych źródeł, w tym $z$ działalności leczniczej, co przyczyniało się do pogarszania, i tak już katastrofalnej, sytuacji finansowej instytutu. Odmowa dostaw towarów i usług, powodująca bezpośrednie zagrożenia dla bezpiecznego procesu leczenia, egzekucje komornicze, ogromne koszty obsługi nadmiernego zadłużenia to kolejne skutki utraty płynności finansowej przez CO-I w latach 2007-2011.

Zapaść finansowa CO-I wywołała również skutki długoterminowe, odczuwalne do dziś. W okresie nadmiernego zadłużenia znacznie ograniczono inwestycje odtworzeniowe i rozwojowe, co spowodowało dekapitalizację majątku trwałego, a zwłaszcza aparatury medycznej i infrastruktury technicznej. $Z$ powodu stałego przeterminowanego zadłużenia w stosunku do Zakładu Ubezpieczeń Społecznych i Urzędu Skarbowego nie wykorzystano szansy na realizację inwestycji, jaką była perspektywa finansowa środków Unii Europejskiej w latach 2007-2013.

Przygotowanie założeń programu naprawczego poprzedziła wnikliwa analiza sytuacji w CO-I, zarówno w obszarze finansowym i kadrowym, jak i istniejącego zaplecza o charakterze organizacyjnym. Określono cel i zakres zmian, zidentyfikowano ryzyka, powołano zespół projektowy składający się $z$ grona ekspertów, dzieląc między nich odpowiedzialność za realizację poszczególnych etapów programu. Warto podkreślić, że nie była to praca zlecona zewnętrznej firmie consultingowej, ale oparta na działaniach ludzi i doświadczeniach uzyskanych $z$ wdrażania podobnych procesów na mniejszą skalę w IHT w latach 2006-2010.

Harmonogramy proponowanych zmian restrukturyzacyjnych i organizacyjnych przedstawiono w trakcie procedury konkursowej na funkcje dyrektora CO-I pod koniec 2011 roku i zostały pozytywnie ocenione przez komisję konkursową. Uzyskały również akceptację Rady Naukowej CO-I, która rekomendowała kandydaturę autora niniejszej publikacji do pełnienia funkcji dyrektora ministrowi zdrowia, którym w tym czasie był Pan Bartosz Arłukowicz. Minister zdrowia przychylił się do zaproponowanych zmian restrukturyzacyjnych i 26 stycznia 2012 roku mianował kandydata do pełnienia funkcji dyrektora CO-I na 4-letnią kadencję. 


\section{Wdrażanie programu naprawczego w CO-I}

\section{Działalność lecznicza}

W realizacji planu naprawczego w pierwszej kolejności skoncentrowano się na wypracowaniu wśród kadry kierowniczej poszczególnych komórek organizacyjnych CO-I postawy menadżera. Z każdym przeprowadzono cykl spotkań w celu wypracowania indywidualnej strategii naprawczo-rozwojowej. Początkowo starano się zdefiniować profil działalności danej komórki organizacyjnej, tj. ustalić rodzaj i liczbę świadczeń, jakie są w niej realizowane. Szczegółowo omówiono bieżącą sytuację związaną $z$ wykorzystaniem zasobów i długością kolejki pacjentów oczekujących na udzielenie świadczeń zdrowotnych. Przeanalizowano sytuację kosztowo-przychodową, w tym wynik finansowy, liczbę zlecanych badań diagnostycznych, liczbę zatrudnionego personelu - zarówno w odniesieniu do liczby łóżek posiadanych, jak i obłożonych. W każdej jednostce kosztowej przeanalizowano przychody za 2011 rok, wyodrębniając miesiące najmniej i najbardziej rentowne i ustalając prawdopodobne przyczyny tych fluktuacji.

Początkiem zmian było przeprowadzenie swoistej „burzy mózgów” $z$ udziałem realizatorów świadczeń w danej komórce organizacyjnej CO-I w celu optymalizacji wykorzystania posiadanych zasobów oraz tego, co należałoby zmienić w otoczeniu danej komórki organizacyjnej, aby poprawić jej wewnętrzną sytuację i usprawnić pracę, w tym ustalano, jakie inwestycje należy poczynić. W wyniku tych ustaleń wspólnie wypracowano strategię przyjęć pacjentów do klinik i zakładów, której elementem był sposób przeprowadzania badań diagnostycznych i konsultacji, w tym na przykład anestezjologicznych przed przyjęciem do kliniki zabiegowej. W klinikach narządowych powołano wielospecjalistyczne zespoły (MDT, multidisciplinary teams) w celu ustalania indywidualnego planu leczenia chorych.

W większości komórek organizacyjnych CO-I należało przeprowadzić szkolenia pracowników z zakresu rozliczania świadczeń zdrowotnych, a tym samym udoskonalić proces sprawozdawczości do NFZ. Podjęto decyzje o przeorganizowaniu niewykorzystanych zasobów w poszczególnych klinikach i zakładach, między innymi poprzez konsolidację lub likwidację i przekazanie ich na stan komórek, dla których przeszkodą w dalszym rozwoju był brak wystarczającej ilości sił i środków. Skrócenie czasu wykonywania podstawowych badań diagnostycznych uzyskano między innymi poprzez reorganizację gabinetów pobrań krwi. Wydłużono czas pracy poradni specjalistycznych stanowiących pierwszy etap na drodze pacjenta do realizacji świadczeń medycznych. Przeorganizowano pracę anestezjologów i bloku operacyjnego poprzez bardziej efektywne wykorzystanie zasobów; skrócono między innymi czas między poszczególnymi zabiegami, wydłużono czas pracy i wprowadzono system monitorowania efektywności jego wykorzystania. Na bieżąco analizowano, w jakim stopniu jest wykorzystywany czas użytkowania bloku operacyjnego oddanego do dyspozycji poszczególnym oddziałom zabiegowym klinik. Wprowadzono wcześniejsze konsultacje anestezjologiczne. Skrócono czas okołooperacyjny poprzez wprowadzenie systemu wcześniejszego przygotowywania pacjenta do zabiegu operacyjnego.

Równolegle do wyżej opisanych działań wprowadzono system controllingu, polegający na monitorowaniu wykorzystania łóżek szpitalnych oraz długości kolejek pacjentów oczekujących na udzielenie świadczeń zdrowotnych. Stałemu monitorowaniu poddano prawidłowość rozliczania i sprawozdawania wykonania świadczeń zdrowotnych do NFZ. Wprowadzono konsultacje w zakresie kodowania świadczeń zdrowotnych między komórkami organizacyjnymi a działem odpowiedzialnym za sprawozdawczość tych świadczeń. $Z$ miesięczną częstotliwością kontrolowano przychody i stopień realizacji kontraktu $z$ NFZ przez poszczególne komórki organizacyjne. Prowadzono systematyczną analizę liczby zlecanych badań diagnostycznych, efektywności wykorzystania bloku operacyjnego i efektywności pracy zakładów i pracowni diagnostycznych. Po zakończeniu każdego kwartału przeprowadzano kompleksową analizę obrazującą globalny efekt realizacji kontraktu. Wnioski $z$ tych analiz i bieżące problemy poddawano dyskusji na cotygodniowych spotkaniach dyrekcji instytutu [5].

\section{Działalność naukowa}

W ramach programu naprawczego podjęto także działania, których celem było obniżenie kosztów prowadzenia badań naukowych i poprawa ich efektywności. Zmianom uległa struktura pionu naukowego poprzez konsolidację i/lub likwidację dotychczasowych samodzielnych jednostek CO-I. Wspieranie globalnej aktywności naukowej odbywało się także poprzez przestrzeganie umowy o zakazie konkurencji dla pracowników naukowych oraz weryfikację indywidualnej aktywności naukowej, mierzonej przede wszystkim liczbą wypracowanych IF (impact factor) w danym przedziale czasowym. Pracownicy naukowi niespełniający odpowiednich 
kryteriów byli pozbawiani etatów naukowych; dla pozostałych wprowadzono system premiowania finansowego proporcjonalny do indywidualnej aktywności naukowej.

Warto podkreślić, że w tym samym czasie, gdy liczba pracowników naukowych zmniejszyła się o $40 \%$, liczba prac naukowych wzrosła prawie 2-krotnie, a sumaryczny indeks oddziaływania IF - aż o $30 \%$. Z danych opublikowanych przez Narodowe Centrum Nauki (NCN) wynikało ponadto, że CO-I uzyskała w tym czasie największą liczbę grantów spośród wszystkich jednostek badawczych spoza Polskiej Akademii Nauk. Konsekwencją było przyznanie CO-I w 2013 roku - w ocenie parametrycznej MNiSW - kategorii A. Jej uzyskanie pozwoliło na wielokrotne zwiększenie wysokości dotacji na realizację zadań naukowych instytutu, znosząc tym samym obciążenia kosztami działalności naukowej CO-I $z$ innych źródeł finansowania [5].

\section{Działalność ekonomiczno-finansowa}

Działania naprawcze skoncentrowano przede wszystkim na zwiększeniu efektywności realizacji kontraktu $z$ NFZ. Strategia była ukierunkowana również na zmniejszenie kosztów poprzez czasowe zamrożenie wysokości wynagrodzeń, wycenę kosztów badań diagnostycznych na potrzebę rozliczeń wewnętrznych i monitorowanie ich wartości oraz zleceń, a także monitorowanie efektywności czasu pracy klinik, zakładów i pracowni diagnostycznych oraz działów administracyjnych. Wprowadzenie nowego regulaminu funkcjonowania działu zamówień publicznych pozwoliło na uniknięcie kosztownych błędów formalnoprawnych, a outsourcing drobnych usług medycznych i niemedycznych oraz wypowiedzenie poprzednich umów najmu i przeprowadzenie ich w duchu obowiązujących przepisów prawa pozwoliło na dodatkowe ograniczenie kosztów i zwiększenie przychodów o kolejnych kilka milionów złotych rocznie. Należy również podkreślić, że kilkuset pracowników złożyło wnioski o zmianę formy pracy na elastyczną lub równoważną, co pozwoliło na lepsze wykorzystanie kadry medycznej i pomocniczej bez konieczności ponoszenia dodatkowych kosztów związanych z pracą w godzinach nadliczbowych.

Poprawa efektywności finansowej w CO-I w latach 2012-2015 obejmowała kilka etapów. Okres od lutego 2012 roku do 30 czerwca 2012 roku charakteryzowały całkowity brak płynności finansowej i bardzo wysokie koszty obsługi długu (kilkanaście $\mathrm{mln}$ zł rocznie). Poza zobowiązaniami przeterminowanymi były również zobowiązania przejęte przez firmy windykacyjne, w wysokości ponad $65 \mathrm{mln}$ zł, oraz bardzo ograniczone inwestycje odtworzeniowe i brak inwestycji rozwojowych. W dniu 30 czerwca 2012 roku, środkami pozyskanymi z Oddziału w Gliwicach (75 mln zł) oraz Oddziału w Krakowie (10 mln zł), została jednorazowa spłacona nadmierna część zadłużenia oraz wyeliminowano dodatkowe koszty związane ze spłatą jego oprocentowania.

Od 1 lipca 2012 roku do 30 października 2013 roku uzyskano zrównoważenie przychodów i wydatków, a utrzymująca się - wprawdzie na niskim poziome, ale dodatnia płynność finansowa - umożliwiła wdrożenie kluczowych działań proefektywnościowych, między innymi takich, jak: $z$ miana systemu wynagradzania $z$ wprowadzeniem elementów płacy motywacyjnej i wyeliminowaniem nieuzasadnionych składników wynagrodzenia, reorganizacja pracy klinik i zakładów w celu poprawy funkcjonowania, warunków leczenia i zwiększenia efektywności realizowanych procedur medycznych, wydłużenie czasu pracy przychodni, wydłużenie czasu pracy bloku operacyjnego, wdrożenie procedur controllingu, optymalizacja rozliczeń z NFZ, ekonomicznie uzasadniony outsourcing części działalności pozamedycznej. Odzyskanie i utrzymanie zrównoważonej i stabilnej sytuacji finansowej było koniecznym warunkiem uruchomienia dalszych procesów restrukturyzacji i rozwoju CO-I.

Od 1 listopada 2013 roku do 30 września 2014 roku pozytywne efekty działań restrukturyzacyjnych pozwoliły na zgromadzenie nadwyżki finansowej niezbędnej do zrealizowania regulacji wynagrodzeń, gdyż „odziedziczona” po okresach poprzednich struktura wynagrodzeń była dalece nieoptymalna. Szczególnie negatywnym zjawiskiem było bardzo duże zróżnicowanie płac w ramach jednorodnych grup stanowisk. Dokonana regulacja płac objęła wszystkie grupy pracownicze. Uzyskano znaczne ujednolicenie wynagrodzeń kosztem zaangażowania dodatkowych środków finansowych przekraczających $10 \mathrm{mln}$ zł w skali roku. W tym czasie rozpoczęto także program inwestycyjny, tworząc gabinety dla specjalistycznej przychodni nowotworów narządowych, modernizując oddział chemioterapii dziennej wraz z centralną rozpuszczalnię cytostatyków, a także przygotowano listę priorytetowych inwestycji, których realizacja była konieczna ze względu na bieżące potrzeby oraz wymagania stawiane przez tak zwany pakiet onkologiczny.

Od 1 października 2014 roku do października 2015 roku finanse CO-I w stosunku do okresu wyjściowego wykazywały dalsze wzrosty przychodów. Najważniejsze to: zwiększenie kontraktu z NFZ (kwota wzrostu o 30,5 mln zł, tj. 7,4\% wzrostu 
w stosunku do 2013 r.), wzrost dotacji statutowej (o kwotę 10,9 mln z1, tj. 186,5\% wzrostu w stosunku do 2013 r.), zwiększenie dotacji w ramach Narodowego Programu Zwalczania Chorób Nowotworowych (o kwotę 1,2 mln zł, tj. o 9,8\% w stosunku do 2013 r.), wzrost przychodów $z$ tytułu realizowanych projektów naukowo-badawczych (na kwotę 93 tys. z1, tj. o 4,2\% w stosunku do 2013 r.), wzrost pozostałych przychodów finansowych (o 300 tys. z1, tj. o 63,5\% w stosunku do $2013 \mathrm{r}$.).

Dobra kondycja finansowa instytutu została dodatkowo wzmocniona większym tempem wzrostu sprzedaży świadczeń medycznych (ogólna kwota wzrostu wyniosła 43,5 mln złotych w 2014 r. w stosunku do roku poprzedniego). W analizowanym okresie koszty w stosunku do przychodów zwiększały się wolniej, w tym koszty związane $z$ działalnością operacyjną instytutu wykazywały tendencję wzrostową ze względu na rosnący kontrakt i wyższą liczbę realizowanych świadczeń medycznych [6].

\section{Działalność inwestycyjna}

Zyski osiągane przez CO-I w latach 2012-2015 były głównym źródłem finansowania jego rozwoju i modernizacji. Stanowity także zabezpieczenie na wypadek nieprzewidzianych wydatków czy przejściowych trudności. Ustabilizowane finanse CO-I dały w końcu rzetelną podstawę do aplikowania o środki zewnętrzne, przede wszystkim pochodzące $z$ programów operacyjnych Unii Europejskiej perspektywy finansowej 2014-2020.

W marcu 2014 roku, na bazie istniejących już jednostek CO-I, utworzono Zakład Patologii i Diagnostyki Laboratoryjnej. Po gruntownej modernizacji pomieszczeń został on wyposażony w najnowocześniejszy sprzęt laboratoryjny linii technologicznej workflow, która umożliwiła skrócenie przeddiagnostycznego procesu obiegu materiału histopatologicznego. W czerwcu 2014 roku uruchomiono po modernizacji Oddział Chemioterapii Dziennej, który dysponuje 50 miejscami dziennymi, klimatyzowanymi salami oraz salami obserwacyjnymi do potrzeb oceny stanu chorego po udzieleniu świadczenia. We wrześniu 2014 roku rozpoczęła w nim działalność nowoczesna pracownia cytostatyczna, $z$ całkiem zautomatyzowanym procesem rozpuszczania leków przy zachowaniu specjalnych warunków jałowości. Ponadto zmodernizowano i wyposażono w nowy sprzęt medyczny wszystkie gabinety poradni specjalistycznej. Na ul. Wawelską, do pięknej i historycznej siedziby instytutu, przeniesiono jego administrację, a zwolnione w ten sposób pomieszczenia na Ursynowie, po kapitalnym remoncie i adaptacji, służą dziś pacjentom - przede wszystkim zgłaszającym się do onkologa po raz pierwszy na szybką diagnostykę onkologiczną prowadzoną w warunkach ambulatoryjnych oraz do Zakładu Psychoonkologii. Całkowicie przebudowano i wyremontowano hall główny instytutu oraz zmodernizowano Klinike Nowotworów Układu Chłonnego, Klinikę Nowotworów Tkanek Miękkich, Kości i Czerniaków, Klinikę Endokrynologii Onkologicznej, a także kupiono do zakładów diagnostycznych i terapeutycznych aparaturę medyczną, w tym tomografy komputerowe, aparat do badania rezonansu magnetycznego, kardiomonitory, aparaty radiologiczne i ultrasonograficzne, systemy planowania i aparaty do radioterapii oraz inne. Rozpoczęto także budowę Oddziału Badań Klinicznych Wczesnych Faz [6].

\section{Skutki wdrożenia}

\section{programu naprawczego w CO-I}

W wyniku wdrożenia programu naprawczego CO-I stał się w 2015 roku instytutem badawczym bez problemów finansowych, zmodernizowanym $\mathrm{w}$ kluczowych miejscach przeznaczonych dla chorych i pracowników. Istotnie zwiększono potencjał naukowy i odmłodzono kadrę naukową. Kliniki Centrum Medycznego Kształcenia Podyplomowego na bazie CO-I prowadzą i koordynują krajowe kształcenie podyplomowe w tytułowych dziedzinach - w Warszawie w zakresie onkologii klinicznej, a w oddziale CO-I w Gliwicach w zakresie radioterapii onkologicznej. Centrum Edukacyjno-Konferencyjne wokół auli im. prof. Tadeusza Koszarowskiego, po gruntownym remoncie i modernizacji, służy dziś 3 salami wykładowymi, aulą i biblioteką przygotowanymi na jednoczesną obsługę 500 słuchaczy.

Kapituła Wektora Pracodawców RP dostrzegła w 2014 roku w programie naprawczym CO-I właściwy kierunek kształtowania zmian w publicznym sektorze ochrony zdrowia. Wyróżnienie przyznano za „efektywną restrukturyzację publicznych instytutów medycznych. Za przywracanie pacjentom onkologicznym nadziei na podjęcie szybkiego leczenia" [6].

\section{Działania organizacyjno-prawne zmierzające do połaczenia CO-I z IHT}

Po wdrożeniu zasadniczych etapów programu naprawczego CO-I kolejnymi celami stawianymi CO-I oraz IHT przez ministra zdrowia w ramach zmian obejmujących krajowy system opieki onkologicznej było zwiększenie dostępności, bezpieczeństwa i skuteczności diagnostyki i leczenia 
chorych na wszystkie rodzaje nowotworów, w tym narządów litych i hematologicznych. W tym celu wykorzystano ustalenia zespołu roboczego powołanego w 2011 roku w MZ, które przewidywały polączenie CO-I z IHT w Narodowy Instytut Onkologii i Hematologii (NIOH) wraz z odtworzenie wokół niego sieci centrów onkologicznych w oparciu o certyfikowane i audytowane wielospecjalistyczne jednostki o typie Comprehensive Cancer Centers. Nadrzędnym celem działalności sieci onkologicznej miało być ujednolicenie w kraju i standaryzacja wielospecjalistycznych świadczeń diagnostycznych i skojarzonej terapii oraz ułatwienie do nich dostępu chorym na nowotwory [7-9].

Formalno-prawną możliwość utworzenia NIOH $z$ siedzibą w Warszawie i Oddziałami w Gliwicach i Krakowie w wyniku połączenia CO-I $z$ IHT określał art. 7 ustawy z 30 kwietnia 2010 roku o instytutach badawczych (Dz.U. nr 96, poz. 618 , z późn. zm.). Przedmiotowa ustawa stała się instrumentem prawnym sprzyjającym konsolidacji sektora badawczego, jeżeli minister nadzorujący uznał, że łączenie instytutów jest uzasadnione merytorycznie, organizacyjnie i finansowo. Zgodnie $z$ przepisami tej ustawy połączenia instytutów dokonuje Rada Ministrów w drodze rozporządzenia, na wniosek złożony przez ministra nadzorującego, po zasięgnięciu opinii ministra właściwego do spraw nauki. Rada Ministrów, $z$ inicjatywy ministra właściwego do spraw zdrowia, może w drodze łączenia instytutów tworzyć także Państwowe Instytuty Badawcze (PIB), jako jednostki o znaczącym potencjale kadrowym i aparaturowym zdolne prowadzić interdyscyplinarne badania naukowe, a jednocześnie wypełniać ważne $z$ punktu widzenia interesu społecznego zadania państwowe [7].

W kontekście planów konsolidacyjnych obu instytutów warta podkreślenia jest wieloletnia tendencja osłabiania się pozycji małych podmiotów o wąskim spektrum usług lub monospecjalistycznym charakterze, w tym Oddziału CO-I w Krakowie i odpowiadającego mu potencjałem ekonomicznym i organizacyjnym IHT, które w kontakcie $\mathrm{z}$ monopolistą na rynku w kontraktowaniu usług mają zarówno utrudnioną pozycję w negocjacjach, jak i w dochodzeniu należności, a także nie mają możliwości, jako podmioty publiczne, świadczenia usług komercyjnych w zakresie, który kompensowałby braki w źródłach finansowania. Ponadto IHT jako podmiot samodzielny nie ma możliwości przesunięcia środków finansowych i pokrycia ujemnych wyników ekonomicznych w ramach wewnętrznego rozrachunku. Połączenie CO-I z IHT umożliwiłoby dywersyfikację źródeł przychodów i adekwatne planowanie kosztów uzyskania przychodów, co - w połączeniu $z$ racjonalizacją wykorzystania posiadanego mienia i możliwości zatrudnianego personelu - stanowiłoby gwarancję stabilności finansowej nowo utworzonego instytutu, a tym samym jego wszystkim oddziałom.

Należy podkreślić, że koncepcja powołania NIOH o statusie PIB nie zakładała utworzenia instytucji hierarchicznie dominującej nad strukturą organizacyjną innych ośrodków onkologicznych i hematologicznych w kraju. Połączenie w jedną strukturę organizacyjną instytutów badawczych, współpracujących i wykorzystujących od dawna wspólną infrastrukturę, miało na celu likwidację ich rozproszenia, co umożliwiłoby poprawę jakości, skuteczności i bezpieczeństwa procedur diagnostyczno-leczniczych realizowanych ze środków publicznych, jak również korzystnie wpłynęłoby na rozwój nauki (zał. 1).

Początkowo planowano utworzenie NIOH poprzez połączenie części warszawskiej CO-I z IHT wraz $z$ odłączeniem oddziałów gliwickiego i krakowskiego, poprzez utworzenie $z$ nich dwóch niezależnych instytutów, tj. odpowiednio śląskiego i małopolskiego centrum onkologii. Taki wniosek uzyskał akceptację wszystkich dyrektorów oddzialów i dyrektora CO-I oraz pozytywną opinię Rady Naukowej w dniu 26 czerwca 2012 roku (zał. 2). $\mathrm{Na}$ osobistą interwencję dyrektorów oddziałów CO-I w Gliwicach (prof. B. Maciejewskiego) i w Krakowie (prof. M. Reinfussa) wniosek ten zmieniono i poddano ponownemu opiniowaniu przez Radę Naukową CO-I. Zmieniony wniosek przewidywał utworzenie Narodowego Instytutu w oparciu o IHT i całe CO-I wraz z oddziałami w Gliwicach i Krakowie. Zasadność tej zmiany tłumaczono obawami odłączonych oddziałów o możliwość skutecznego kontraktowania świadczeń $z$ NFZ ze względu na utratę prestiżu i utratę potencjału naukowego jednostek, a w konsekwencji spadek w ocenie parametrycznej dokonywanej przez MNiSW oraz prawdopodobną utratą samodzielności poprzez wchłonięcie oddziałów przez lokalne uniwersytety medyczne w dalszej perspektywie czasowej.

Uchwały Rad Naukowych CO-I oraz IHT wnioskujące o połączenie obu instytutów w Narodowy Instytut Onkologii i Hematologii im. Marii Skłodowskiej-Curie $z$ siedzibą w Warszawie o statusie PIB zostały podjęte $\mathrm{w}$ trakcie plenarnych posiedzeń 10 czerwca 2013 roku (IHT) i 12 czerwca 2013 roku (CO-I); 12 czerwca 2013 roku przedmiotowe uchwały wraz $z$ wnioskami dyrekcji obu instytutów oraz opiniami związków zawodowych złożono na ręce ministra zdrowia (zał. 3). 
Na potrzebę powołania NIOH o statusie PIB wskazał także zespół Krajowej Rady ds. Onkologii przy ministrze zdrowia ds. standaryzacji i jakości procedur w onkologii na posiedzeniu w dniu 13 maja 2015 roku.

Zgodnie $z$ ustawą o instytutach badawczych połączenie instytutów poprzedzało postępowanie przygotowawcze przeprowadzane przez zespół roboczy mający za zadanie ocenić potrzebę oraz warunki połączenia. Zespół był zobowiązany przedstawić ministrowi nadzorującemu opinię w terminie 3 miesięcy od powołania. Na podstawie tych przepisów minister zdrowia wydał rozporządzenie $z 28$ maja 2015 roku o powołaniu takiego zespołu [10], który w ustawowym terminie wydał opinię (zał. 1) rekomendującą ministrowi zdrowia: 1) połączenie CO-I z IHT $\mathrm{w}$ jeden instytut; 2) nadanie nowo utworzonemu instytutowi nazwy Narodowego Instytutu Onkologii i Hematologii; 3) przejęcie przez nowotworzony instytut pracowników CO-I oraz IHT; 4) przejęcie przez nowotworzony instytut praw i obowiązków CO-I oraz IHT na zasadzie sukcesji uniwersalnej; 5) dokonanie połączenia CO-I $z$ IHT według stanu ze spisu $z$ natury oraz sprawozdań finansowych sporządzonych w dniu poprzedzającym dzień łączenia instytutów; 6) nadanie nowotworzonemu instytutowi statutu, w którym zostaną określone zadania obejmujące działalność naukową i leczniczą, w tym realizowanie programów polityki zdrowotnej, działalność dydaktyczną i wydawniczą, a także uczestnictwo w systemie ochrony zdrowia, ekonomiki procesów leczniczych, informacji naukowej, usług badawczych, ekspertyz oraz opracowywania metodologii i prowadzenie szkoleń specjalistycznych $\mathrm{z}$ zakresu onkologii, hematologii, transfuzjologii klinicznej i laboratoryjnej oraz innych dyscyplin pokrewnych, a także związanych $z$ aktualizowaniem algorytmów i wytycznych diagnostyczno-leczniczych stosowanych u chorych na nowotwory i choroby krwi oraz medycznych zasad pozyskiwania, przechowywania i przetaczania krwi i preparatów krwiopochodnych obowiązujących w jednostkach organizacyjnych publicznej służby krwi i podmiotach realizujących świadczenia z zakresu krwiolecznictwa; 7) wszczęcie procesu nadania statusu PIB nowo utworzonemu Narodowemu Instytutowi Onkologii i Hematologii w celu spełnienia przesłanek, które legły u podstaw podjęcia decyzji o połączeniu CO-I i IHT.

Prace zmierzające do nadania instytutowi statusu PIB miały być objęte odrębną procedurą już po połączeniu jednostek, ponieważ zgodnie $z$ artykułem 21 ustęp 3 wyżej wymienionej ustawy wniosek o nadanie statusu PIB powinien być poprzedzony dokonaniem oceny dotychczasowej działalności instytutu przez Komitet Ewaluacji Jednostek Naukowych.

Po przedstawieniu ministrowi zdrowia opinii rekomendującej polączenie, stosownie do przepisu zawartego w $\$ 12$ ustęp 1 rozporządzenia Rady Ministrów $z 17$ listopada 2010 roku w sprawie tworzenia, łączenia, podziału, reorganizacji, przekształcania, włączania lub likwidacji instytutów badawczych (Dz.U. nr 230, poz. 1512) w celu dokonania oceny stanu majątkowego i organizacyjno-prawnego łączonych instytutów oraz opracowania warunków, na jakich zostanie dokonane ich połączenie, Minister Zdrowia - Pan Marian Zembala - mocą zarządzenia z 27 sierpnia 2015 roku powołał komisję [11]. Rady Naukowe obu instytutów zgłosiły kandydatów do prac w tej komisji; 10 września 2015 roku odbyło się jej pierwsze posiedzenie, a 5 października 2015 roku - drugie i ostatnie. Komisja przygotowała opinię w sprawie połączenia instytutów, tj. IHT i CO-I w Warszawie wraz z oddziałami w Gliwicach i w Krakowie (zał. 4).

Dnia 13 października 2015 roku projekt rozporządzenia Rady Ministrów w sprawie utworzenia NIOH (KRM-110-101-15) został opublikowany przez Rządowe Centrum Legislacji (RCL) i po konsultacjach publicznych, prowadzonych od 13 do 20 października 2015 roku, został przekazany przez ministra zdrowia do Stałego Komitetu Rady Ministrów (KRM) w celu umieszczenia w porządku obrad najbliższego posiedzenia Rady Ministrów. W rozporządzeniu przewidywano wejście $\mathrm{w}$ życie jego postanowień 1 stycznia 2016 roku (zał. 5).

\section{Dlaczego wstrzymano wydanie rozporządzenia KRM w sprawie utworzenia NIOH?}

Bez podania przyczyny proces legislacyjny w sprawie utworzenia NIOH nagle wstrzymano. Minister Zdrowia - Pan Marian Zembala - nie poinformował o tym zamiarze Rad Naukowych ani dyrektora obu łączonych instytutów. Na podstawie docierających informacji medialnych wydaje się, że o takiej decyzji zdecydowała prowadzona jednoczasowo $z$ inicjatywy ministra $z$ drowia $-z$ pominięciem przepisów prawa i bez zgody dyrektora oraz bez opinii Rady Naukowej CO-I - próba wydzielenia z CO-I majątku należącego do Oddziału w Gliwicach, co uniemożliwiło dokończenie procesu konsolidacji instytutów ze względu na brak tożsamości wniosków, opinii, uchwał, dokumentów, a przede wszystkim podmiotów, które były przedmiotem analizy i postępowania przygotowawczego w tej sprawie (zał. 1, 4 i 5) [10, 11]. 
Działania ministra zdrowia, zmierzające do wydzielenia Oddziału CO-I w Gliwicach i jego uniezależnienia, zmaterializowały się po przesłaniu do $\mathrm{MZ}$ wyniku audytu, który wykazał drastycznie niesprawiedliwe i podejmowane $z$ naruszeniem prawa zasady wynagradzania $w$ tym oddziale oraz informacji o podjętych w tej sprawie czynnościach przez dyrektora CO-I. Należały do nich między innymi działania polegające na wzmożeniu nadzoru nad działalnością oddziału i jego dyrektora oraz okresowym wstrzymaniu niektórych fakultatywnych składników wynagrodzeń do czasu wypracowania nowego, jednolitego, transparentnego i motywacyjnego regulaminu wynagradzania w całym instytucie.

Wkrótce po tym fakcie Minister Zdrowia - Pan Marian Zembala - zakomunikował dyrektorowi CO-I swoją decyzję o woli i potrzebie podziału CO-I poprzez wydzielenie Oddziału w Gliwicach i utworzenie Śląskiego Centrum Onkologii. Decyzję $\mathrm{w}$ tej sprawie podjął $z$ urzędu i wszczął postępowanie przygotowawcze, w którym ujawniono, że proces podziału i odłączenia Oddziału CO-I w Gliwicach został już wstępnie przygotowany przez członków dyrekcji i pracowników tego oddziału, których minister zdrowia powołał do zespołu roboczego, z pominięciem przedstawicieli CO-I z Krakowa i Warszawy. Proces podziału CO-I wszczęto mimo finalizowania połączenia CO-I $z$ IHT oraz przewidywanych negatywnych skutków takiego podziału dla całego instytutu i jego oddziałów, o czym dyrektor instytutu wielokrotnie informował MZ.

Proces legislacyjny mający na celu wyłączenie oddziału gliwickiego $z$ CO-I prowadzono $\mathrm{w}$ pośpiechu, $z$ pominięciem dyspozycji ustawy o jednostkach badawczych; 22 września 2015 roku minister zdrowia wydał zarządzenie w sprawie powołania zespołu roboczego do przeprowadzenia postępowania przygotowawczego służącego dokonaniu oceny potrzeby oraz warunków wydzielenia z CO-I Oddziału w Gliwicach w celu utworzenia Śląskiego Instytutu Onkologii [12, 13]. Minister zdrowia nie przeprowadził jednak żadnego postępowania, by określić zasadność i potrzebę utworzenia nowego instytutu, nigdzie nie określono również w odniesieniu do nowego instytutu: 1) dziedzin i zakresu badań naukowych lub prac rozwojowych ani sektorów gospodarki i innych obszarów istotnych dla funkcjonowania państwa, w jakich powstała potrzeba utworzenia tego instytutu; 2) zasadności prowadzenia badań naukowych i prac rozwojowych; 3) potencjału wdrożeniowego w obszarze dziedzin i zakresu badań naukowych lub prac rozwojowych; 4) możliwości spełnienia warunków wymaganych do utworzenia instytutu.
Minister zdrowia nie przedstawił też żadnej opinii zawierającej: 1) ocenę skutków finansowych utworzenia instytutu, w tym wpływu na sektor finansów publicznych, 2) ocenę wpływu na konkurencyjność gospodarki przedsiębiorstw oraz rynek pracy; 3) analizę konkurencji na rynku badań w dziedzinach nauki, w których miałby działać nowo utworzony instytut; 4) analizę aktualnej i przyszłej sytuacji na rynkach, na których mogłyby być wdrażane wyniki badań naukowych lub prac rozwojowych prowadzonych przez nowo utworzony instytut.

Zespół roboczy powołany przez ministra zdrowia nie spełniał ponadto wymogów ustawowych przewidzianych dla zespołu przygotowawczego ds. utworzenia instytutu ani nie był uprawniony do pełnienia takiej roli. Działania MZ naruszały integralność CO-I i jego interes gospodarczy, ponieważ nie uwzględniały żadnych zasad podziału majątku, odsyłając do późniejszych umów, które mogły nie być nigdy zawarte. Mogło to skutkować upadkiem wszystkich podmiotów wymienionych $\mathrm{w}$ projekcie rozporządzenia o podziale majątku CO-I i dezorganizacją działalności naukowej, gdyż do czasu zawarcia takich umów nie byłoby możliwe ani dopuszczalne prowadzenie badań klinicznych i naukowych oraz ich rozliczanie $z$ MNiSW, NCN, Narodowym Centrum Badań i Rozwoju oraz innymi podmiotami finansującymi naukę.

Powyższe stanowisko, $z$ uwagami i zastrzeżeniami do wyniku prac komisji, złożył dyrektor CO-I. Zespół roboczy tych uwag nie uwzględnił. W głosowaniu nad opinią, liczbą głosów 6:5, została ona przyjęta. Dyrektor CO-I głosował przeciw jej przyjęciu i wystąpił do $\mathrm{MZ}$ o wydanie kopii protokołu $z$ głosowania oraz kopii stanowisk zajętych przez członków zespołu roboczego. Ministerstwo Zdrowia nie udzieliło informacji i nie wydało żadnego $z$ tych dokumentów.

Mimo to minister zdrowia zamierzal dokonać $z$ urzędu podziału, przygotowując własny projekt rozporządzenia KRM w sprawie podziału CO-I — bez komisji, która dokonałaby oceny oraz opracowała warunki tego podziału (tzw. komisja majątkowa). Informacja o przygotowaniu wyżej wymienionego projektu rozporządzenia, mimo braku postępowania przed komisją majątkową, znalazła się na stronach MZ już 13 października 2015 roku [12]. Projekt ten nie został udostępniony CO-I, choć złożono pisemny wniosek o wydanie kopii projektu w trybie dostępu do informacji publicznej. Minister nie ujawnił rodzaju ani sposobu zamierzonego i zapowiadanego $\mathrm{w}$ mediach podziału instytutu oraz nie poinformował o tym dyrektora i Rady Naukowej CO-I. 
Dnia 13 października 2015 roku dyrektorowi CO-I, jako członkowi komisji majątkowej mającej na celu dokonanie oceny oraz opracowanie warunków podziału CO-I, przesłano zaproszenie do udziału w jej pracach. Komisję tę powołano jednak dopiero następnego dnia, tj. 14 października 2015 roku [13]. Dyrektor Departamentu Budżetu MZ, pismem z 13 października 2015 roku, przesłanym do CO-I w dniu poprzedzającym wydanie zarządzenia, nie była przewodniczącą komisji i nie była uprawniona do jej zwołania. Celem zwołania tej komisji, po faktycznym podjęciu decyzji o podziale CO-I juz kilka dni wcześniej, było jedynie uzyskanie podpisów jej członków pod warunkami podziału ustalonymi wcześniej przez ministra zdrowia. Dowodem tego byl projekt rozporządzenia w sprawie podziału CO-I z 13 października 2015 roku przedstawiony na kolegium MZ i opublikowany na stronach MZ jeszcze przed projektem zarządzenia $\mathrm{w}$ sprawie powołania komisji majątkowej, co potwierdza uzasadnienie projektu rozporządzenia o podziale CO-I zamieszczonego 29 października 2015 roku na stronach internetowych RCL, $z$ którego wynikało tylko tyle, że komisja majątkowa została powołana — bez bliższego wskazania, czy i kiedy zakończyła prace oraz jaki był ich wynik [14].

Ponadto przedmiotowa komisja majątkowa miała w swoim w składzie nienależycie umocowaną osobę z Rady Naukowej. Rada Naukowa CO-I desygnowała swojego przedstawiciela do prac w komisji majątkowej $z$ naruszeniem regulaminu Rady Naukowej, albowiem czynności tej dokonał jednoosobowo tylko przewodniczący (prof. J. Fijuth), nie informując członków Rady ani wszystkich członków jej Prezydium. Osoba, która została zgłoszona do prac komisji majątkowej w charakterze przedstawiciela Rady Naukowej CO-I, działała wyłącznie we własnym imieniu i nie była jej przedstawicielem. Nadużycie uprawnień i pozaregulaminowe decyzje przewodniczącego Rady Naukowej CO-I spowodowały odcięcie członków Rady od informacji o poczynaniach podejmowanych przez ministra zdrowia w sprawie warunków podziału majątku CO-I i skutkowały pozbawieniem wpływu Rady Naukowej na losy instytutu. Dyrektor CO-I nie wyraził zgody na udział w pracach przedmiotowej komisji, o czym poinformował odrębnym pismem 15 października 2015 roku Podsekretarza Stanu MZ - Panią Annę Łukasik, a także ministra zdrowia i premier rządu.

W tym kontekście zasadnicze wątpliwości budzi podjęta przez ministra zdrowia decyzja o odwołaniu 26 października 2015 roku dyrektora CO-I, którą wobec powyższego należy poczytywać jako usunięcie przeszkody i utorowanie sobie drogi do nieskrępowanego dysponowania mieniem instytutu. Minister zdrowia wskazał wprost na taką przyczynę w decyzji o odwołaniu dyrektora, uznając jego działania za „,niezgodne $z$ zasadami praworządności w związku $z$ odmową współpracy $z$ organem nadzorującym Instytut $\mathrm{w}$ zakresie prac komisji powołanej zarządzeniem ministra zdrowia 14 października 2015 roku w sprawie komisji mającej na celu dokonanie oceny oraz opracowania warunków, na jakich zostanie dokonany podział Centrum Onkologii - Instytutu im. Marii Skłodowskiej-Curie”.

Po odwołaniu dyrektora Minister Zdrowia - Pan Marian Zembala —zapowiedział w mediach 28 października 2015 roku, że dokona podziału CO-I na najbliższym posiedzeniu rządu. Ze względu na to, że ostatnie posiedzenie ustępującego rządu miało nastąpić 3 listopada 2015 roku, zdecydowano o nadzwyczajnym skróceniu terminu konsultacji publicznych przedmiotowego projektu rozporządzenia o podziale Instytutu do $3 \mathrm{dni}$ (w tym 2 dni wolnych od pracy), tj. do godz. 10:00 rano 2 listopada 2015 roku [14]. Krótkie terminy wyznaczone na konsultacje publiczne - w praktyce uniemożliwiające zarejestrowania tego faktu w obiegu kancelaryjnym ministerstw $i$ innych zainteresowanych podmiotów (nie mówiąc o przygotowaniu opinii) — stały się w tym przypadku fikcją i praktycznie pozbawiły te podmioty możliwości wyrażenia stanowiska.

Nie do przyjęcia było także uzasadnienie narzuconego jednodniowego terminu konsultacji, które wynikało $z$ faktu, „(...) iż przedmiotowe rozporządzenie ma wejść w życie $z$ dniem 6 listopada 2015 roku i w tym dniu ma nastąpić podział" [14]. Data wejścia w życie przedstawionego do konsultacji projektu rozporządzenia była nierealna, gdyż podział dokonany przedmiotowym rozporządzeniem nie zawierał wiążących podzielone jednostki rozwiązań dotyczących rozliczeń i odsyłał do przyszłych i blizej nieokreślonych umów, których zawarcie było dodatkowo obwarowane zgodami wierzycieli. Należy podkreślić, że kierownik CO-I oraz przewodniczący i Prezydium Rady Naukowej także nie podjęli w tym czasie żadnych działań, aby poinformować o zamiarze i sposobie podziału CO-I członków Rady Naukowej i przygotować wspólne stanowisko oraz opinię zgodnie $z$ artykułem 8 ustęp 5 ustawy o instytutach badawczych.

Powyższe działania w sposób oczywisty zagroziły naruszeniem integralności oraz interesów majątkowych i naukowych instytutu, co w kontekście zakończenia postępowania w sprawie połączenia 
całości majątku CO-I z IHT i planowanego utworzenia na tej podstawie NIOH było działaniem na szkodę interesu publicznego. Informowali o tym nie tylko odwołany dyrektor CO-I we wspomnianych wyżej pismach, ale także kierownicy klinik i zakładów naukowych obu instytutów w listach otwartych adresowanych do ministra zdrowia i premier rządu (zał. 6), przewodniczący Rady Głównej Instytutów Badawczych (zał. 7) i Polskiej Unii Onkologii (zał. 8) w pismach adresowanych do ministra zdrowia, minister finansów w piśmie kierowanym do KRM (zał. 9), a także środki masowego przekazu [15-44].

W wymienionych wyżej pismach wskazywano między innymi, że czynione propozycje i tryb postępowania podziałowego CO-I godzą w interes państwowych osób prawnych, a ponadto w przypadku ich realizacji będą dotknięte bezwzględną nieważnością $z$ mocy prawa oraz zagrożone odpowiedzialnością konstytucyjną ministra nadzorującego oraz karną pozostałych osób działających w sprawie. Wydaje się prawdopodobne, że właśnie te okoliczności spowodowały powstrzymanie się ministra zdrowia od podziału majątku CO-I, choć publicznie zapowiadał zamiar wydania przedmiotowego rozporządzenia do ostatnich dni swojego urzędowania.

Trudniejszym do wytłumaczenia pozostaje fakt niewydania rozporządzenia KRM o utworzeniu $\mathrm{NIOH}$, tym bardziej że stwarzało ono realną szansę na dokonanie zmiany zarządzenia ministra zdrowia z 22 września 2015 roku w sprawie powołania zespołu roboczego do przeprowadzenia postępowania przygotowawczego mającego na celu dokonanie oceny potrzeby oraz warunków wydzielenia z CO-I Oddziału w Gliwicach poprzez ustalenie, że przedmiotowe postępowanie będzie dotyczyć wydzielenia tego oddziału $z \mathrm{NIOH}$. Istniała także możliwość rozważenia jednoczasowego wydzielenia $z$ NIOH Oddziału w Krakowie, co byłoby zgodne $z$ pierwotną koncepcją utworzenia NIOH oraz Śląskiego i Małopolskiego Instytutu Onkologii z 2012 roku (zał. 2). Dyrektor CO-I wielokrotnie informował o takiej możliwości, w tym między inymi odrębnym pismem adresowanym do $\mathrm{M} Z \mathrm{w}$ dniu 12 października 2015 roku.

W rezultacie Minister Zdrowia - Pan Marian Zembala - zrezygnował nie tylko $z$ zamiaru podziału majątku CO-I, ale także utworzenia NIOH, o czym poinformowal 4 listopada 2015 roku członków Rady Naukowej CO-I podczas nadzwyczajnego posiedzenia. Relacja $z$ tego wystąpienia jest zawarta w załączniku 10 do niniejszego artykułu.

\section{Podsumowanie}

Kolegia redakcyjne „Medexpressu” oraz „Służby Zdrowia”, przyznając dyrektorowi CO-I w 2015 roku Prymariusza, wskazały na to, że: „ (...) 2015 rok był czasem, w którym onkologia i tematy związane $z$ onkologią zostały wreszcie uznane przez polityków za ważne. Były także elementem dużego dyskursu publicznego. Mówiło się o onkologii, ale prócz tego jest człowiek, który także działał i zrobił wiele ważnych rzeczy dla pacjentów i systemu. Dzięki jego działalności i aktywności Centrum Onkologii stało się placówką nowoczesną, podążającą za trendami medycznymi. Bardzo wiele dobrego stało się dla pacjentów w Centrum, na przykład zmniejszyły się kolejki, a dostęp do specjalistów stał się faktem”.

Niestety, konsekwencja i pryncypialność nie wystarczyły, aby wcielić w życie ambitny projekt restrukturyzacyjny CO-I oraz IHT poprzez utworzenie nowoczesnego i kompleksowego instytutu o krajowym zasięgu oddziaływania i statusie PIB. Rzeczywista potrzeba istnienia takiej jednostki $\mathrm{w}$ wymiarze naukowo-badawczym, klinicznym i edukacyjnym — podległej bezpośrednio ministrowi zdrowia $z$ wyłączeniem autonomii przynależnej na przykład uniwersytetom medycznym - nakazuje nie rezygnować $z$ realizacji tego celu, a co najwyżej odroczyć go w czasie poprzez odstąpienie od postulatu natychmiastowości na rzecz pracy etapowej i szukania koniecznych kompromisów.

Zagrożeniem dla jego urzeczywistnienia mogą się stać - widoczne aż nadto w dotychczasowych staraniach o utworzenie NIOH - ogólne mechanizmy funkcjonowania państwa, które w niewielkim stopniu są ukierunkowane na naprawę jego poszczególnych obszarów. Małe ogniska gasi się ukradkiem za pomocą wiaderka wody, ale w dalszej kolejności nie przeprowadza się procesów naprawczych, które uniemożliwiałyby pojawianie się kolejnych ognisk zapalnych. Dla wygody uprawiania takiej polityki i załatwiania partykularnych interesów nicnierobienie stało się zwyczajnie bezpieczniejsze od podejmowania działań ukierunkowanych na społeczną zmianę. Niepokornych usuwa się na „boczny tor” za pomocą mniej lub bardziej demokratycznych procedur. W odniesieniu do instytutów takie działania mogą przynieść jedynie bezruch i dryf, które nie są w najmniejszym stopniu instrumentami gwarantującymi im bezpieczeństwo, a tym bardziej dalszy rozwój.

Wyjściem $z$ tego stanu rzeczy może być jedynie zmiana polityki polegająca na realizacji ambitnych projektów. W przypadku CO-I oraz IHT byłoby nim utworzenie NIOH o statusie PIB koordynującego 
działanie certyfikowanych i audytowanych wielospecjalistycznych centrów onkologicznych i hematologicznych w sposób zgodny z rzeczywistymi mapami potrzeb zdrowotnych społeczeństwa.

Celem niniejszej publikacji była realizacja ważnego interesu społecznego - udokumentowania kilkuletnich starań Pracowników wielu instytucji publicznych zmierzających do utworzenia Narodowego Instytutu Onkologii i Hematologii im. Marii Skłodowskiej-Curie, a także przesłanek, które legły u podstaw podjęcia takiej decyzji. Udostępniona informacja publiczna - wykorzystana na potrzeby niekomercyjnego celu niniejszej publikacji — może posłużyć także jako wartościowy materiał naukowo-dydaktyczny dla decydentów w przyszłości.

\section{Piśmiennictwo}

1. Dostępne na: https://www.nik.gov.pl/kontrole/wyniki-kontroli-nik/ /pobierz,nik-p-11-095-instytuty-badawcze,typ,kk.pdf.

2. Dostępne na: https:/www.nik.gov.pl/kontrole/wyniki-kontroli-nik/ /pobierz,kzd p_11_095_201111021318211320236301 id0 01, typ,kj.pdf.

3. Dostępne na: https://www.nik.gov.pl/kontrole/wyniki-kontroli-nik/ /pobierz,kzd p_11_095_201111021318211320236301 id1 01, typ,kj.pdf.

4. Dostępne na: http://www.zdrowie.abc.com.pl/akt1/-/akt/print/ /dz-urz-mz-2011-8-67.

5. Monitor — Informator Wewnętrzny Centrum Onkologii — Instytutu im. Marii Skłodowskiej-Curie w Warszawie 2013; 18: 1-9.

6. Monitor - Informator Wewnętrzny Centrum Onkologii — Instytutu im. Marii Skłodowskiej-Curie w Warszawie 2015; 19: 1-23.

7. Warzocha K. Narodowy Instytut Onkologii i Hematologii. Hematologia 2013; 4: 185-196.

8. Warzocha K. Krajowa sieć onkologiczna. Hematologia 2014; 5: 1-21.

9. Warzocha K. Koncepcje zmian systemowych w opiece onkologicznej w Polsce u progu 2015 roku. Hematologia 2014; 5: 179-192.

10. Dostępne na: http://www.infor.pl/akt-prawny/U04.2015.015.0000025, zarzadzenie-ministra-zdrowia-w-sprawie-powolania-zespolu-roboczego-do-przeprowadzenia-postepowania-przygotowawczego-majacego-na-celu-dokonanie-oceny-potrzeby-oraz-warunkow-polaczenia-centrum-onkologii.html.

11. Dostępne na: http://www.infor.pl/akt-prawny/U04.2015.028.0000044, zarzadzenie-ministra-zdrowia-w-sprawie-powolania-komisji-majacej-na-celu-dokonanie-oceny-oraz-opracowanie-warunkow-na-jakich-zostanie-dokonane-polaczenie-centrum-onkologii-instytutu-im-marii-sklodowsk.html.

12. Dostępne na: http://www.mz.gov.pl/ministerstwo/urzad/ustalenia-z-posiedzenia-kierownictwa-ministerstwa-zdrowia/ustalenia-z-obrad-kolegium-ministra-zdrowia.

13. Dostępne na: http://www.infor.pl/akt-prawny/U04.2015.035.0000061, zarzadzenie-ministra-zdrowia-w-sprawie-powolania-komisji-majacej-na-celu-dokonanie-oceny-oraz-opracowanie-warunkow-na-jakich-zostanie-dokonany-podzial-centrum-onkologii-instytutu-im-marii-sklodowskiej.html.

14. Dostępne na: http://legislacja.rcl.gov.pl/projekt/12278457.

15. Dostępne na: http://www.tubagliwic.pl/aktualnosci/czytaj/953/W-Gliwicach-ma-powstac-Slaski-Instytut-Onkologii.

16. Dostępne na: http://wyborcza.pl/1,91446,19097483,mz-odwolal-dyrektora-centrum-onkologii-rezygnuje-szef-gliwickiego.html.
17. Dostępne na: http://fakty.interia.pl/news-dyrektor-centrum-onkologii-odwolany-z-powodu-braku-wspolprac,nId,1910950.

18. Dostępne na: http://www.rynekzdrowia.pl/Serwis-Onkologia/Warszawa-minister-zdrowia-odwolal-prof-Warzoche-ze-stanowiska-dyrektora-CO-I,156235,1013.html.

19. Dostępne na: http://www.haloursynow.pl/artykuly/dyrektor-centrum-onkologii-na-ursynowie-odwolany,4738.htm.

20. Dostępne na: http://www.medexpress.pl/start/ministerstwo-zdrowia-potwierdza-prof-krzysztof-warzocha-odwolany/61962/.

21. Dostępne na: http://www.termedia.pl/mz/Prof-Warzocha-przestal-byc-dyrektorem-Centrum-Onkologii,19537.html.

22. Dostępne na: http://www.dziennikzachodni.pl/artykul/9034768, prof-boguslaw-maciejewski-zlozyl-rezygnacje,id,t.html.

23. Dostępne na: http://m.katowice.wyborcza.pl/katowice/1,106509, 19093241,prof-boguslaw-maciejewski-pobral-wysoka-premie-nie-nalezala.html?disableRedirects $=$ true.

24. Dostępne na: http://wyborcza.pl/TylkoZdrowie/1,137474,19097855,spor-o-narodowy-instytut-onkologii-lekarze-protestuja-przeciwko.html.

25. Dostępne na: http://www.24gliwice.pl/wiadomosci/zamieszanie-w-gliwickiej-onkologii-rezygnacja-dyrektora-maciejewskiego-niszczy-sie-czlowieka/.

26. Dostępne na: http://www.tvs.pl/informacje/prof-boguslaw-maciejewski-odchodzi-z-centrum-onkologii-w-gliwicach-ma-zwrocic-czesc-premii-i-nagrod-oswiadczenie.

27. Dostępne na: http://wyborcza.pl/1,75478,19099159,onkologiczna-wojna-o-pieniadze-jak-centrala-w-warszawie-zabierala.html?disable Redirects $=$ true.

28. Dostępne na: http://m.onet.pl/wiadomosci/kraj,mz3ktf.

29. Dostępne na: http://m.wyborcza.pl/wyborcza/1,105226,19127097, zwiazkowcy-krytycznie-o-sposobie-prac-nad-podzialem-centrum. html.

30. Dostępne na: http://www.tvn24.pl/katowice,51/osrodek-onkologii-w-gliwicach-odlacza-sie-od-instytutu-w-warszawie,590729.html.

31. Dostępne na: http://www.rynekzdrowia.pl/Finanse-i-zarzadzanie/ /Podzial-CO-I-dokonuje-sie-bez-konsultacji-spolecznych-Pracownicy-licza-na-wstrzymanie-procedury,156422,1.html.

32. Dostępne na: http://www.nowiny.gliwice.pl/wydarzenia,6416,0.

33. Dostępne na: http://www.gazetaprawna.pl/artykuly/903220,nie-bedzie-podzialu-centrum-onkologii.html.

34. Dostępne na: http://www.radiomaryja.pl/informacje/rzad-o-podziale-centrum-onkologii/.

35. Dostępne na: http://www.dziennikzachodni.pl/artykul/9055755, centrum-onkologii-bez-podzialu-gliwice-nadal-placa-za-bledy-warszawy,id,t.html.

36. Dostępne na: http://katowice.wyborcza.pl/katowice/1,35063,19134465, gliwice-centrum-onkologii-nie-odlaczylo-sie-od-warszawy-za.html.

37. Dostępne na: http://www.rynekzdrowia.pl/serwis-onkologia/pto-podzial-centrum-onkologii-to-inicjatywa-szkodliwa-i-nieuzasadniona,156485,1013.html.

38. Dostępne na: http://www.rynekzdrowia.pl/finanse-i-zarzadzanie/ /warszawa-podzialu-co-i-na-razie-nie-bedzie,156468,1.html.

39. Dostępne na: http://www.rynekzdrowia.pl/finanse-i-zarzadzanie/ /minister-zdrowia-o-in-vitro-wydzieleniu-co-w-gliwicach-i-unijnych-pieniadzach,156512,1.html.

40. Dostępne na: http://www.termedia.pl/mz/Dokad-powinna-zmierzac-polska-onkologia-,19681.html.

41. Dostępne na: http://www.radiomaryja.pl/informacje/nie-bedzie-polaczenia-centrum-onkologii-z-instytutem-hematologii/.

42. Dostępne na: http://katowice.wyborcza.p//katowice/1,35063,19192328, znow-zadaja-duzych-pieniedzy-od-centrum-onkologii-w-gliwicach.html.

43. Dostępne na: http://www.rynekzdrowia.pl/finanse-i-zarzadzanie/ /instytut-onkologii-w-gliwicach-chce-samodzielnosci-temat-powraca,158459,1.html.

44. Dostępne na: http://www.rynekzdrowia.pl/finanse-i-zarzadzanie/ /akcja-trwa-gliwickie-centrum-onkologii-chce-rozwodu-z-warszawa,159095,1.html. 


\section{Załączniki}

1. Opinia Zespołu Roboczego powołanego zarządzeniem ministra zdrowia z 28 maja 2015 roku zawierająca ocenę potrzeby oraz warunków połączenia Centrum Onkologii - Instytutu im. Marii Skłodowskiej-Curie oraz Instytutu Hematologii i Transfuzjologii.

2. Uchwała nr 14 Rady Naukowej Centrum Onkologii - Instytutu im. Marii Skłodowskiej-Curie z 26 czerwca 2012 roku w sprawie podziału Instytutu na Narodowy Instytut Onkologii im. Marii Skłodowskiej-Curie w Warszawie, Śląski Instytut Onkologii z siedzibą w Gliwicach i Małopolski Instytut Onkologii z siedzibą w Krakowie wraz $z$ odpowiednim wnioskiem dyrektora Instytutu do ministra zdrowia z 30 lipca 2012 roku.

3. Uchwała nr 62 Rady Naukowej Instytutu Hematologii i Transfuzjologii z 10 czerwca 2013 roku i uchwała nr 7 Rady Naukowej Centrum Onkologii - Instytutu im. Marii Skłodowskiej-Curie z 12 czerwca 2013 roku w sprawie połączenia Instytutu Hematologii i Transfuzjologii z Centrum Onkologii - Instytutem im. Marii Skłodowskiej-Curie w Narodowy Instytut Onkologii im. Marii Skłodowskiej-Curie o statusie Państwowego Instytutu Badawczego wraz z odpowiednim wnioskiem dyrektorów Instytutów do ministra zdrowia $z 12$ czerwca 2013 roku.

4. Opinia mająca na celu dokonanie oceny oraz opracowanie warunków, na jakich zostanie dokonane połączenie Centrum Onkologii - Instytutu im. Marii Skłodowskiej-Curie oraz Instytutu Hematologii i Transfuzjologii opracowana przez Komisję powołaną zarządzeniem ministra zdrowia z 28 sierpnia 2015 roku.

5. Projekt rozporządzenia Rady Ministrów w sprawie połączenia Centrum Onkologii — Instytutu im. Marii Skłodowskiej-Curie oraz Instytutu Hematologii i Transfuzjologii w celu utworzenia Narodowego Instytutu Onkologii i Hematologii im. Marii Skłodowskiej-Curie z 12 października 2015 roku.

6. Listy otwarte Kierowników Klinik i Zakładów Naukowych Centrum Onkologii - Instytutu im. Marii Skłodowskiej-Curie oraz Instytutu Hematologii i Transfuzjologii do ministra zdrowia i Prezesa Rady Ministrów z 13 października 2015 roku w sprawie zakończenia prac legislacyjnych zmierzających do utworzenia Narodowego Instytutu Hematologii i Onkologii.

7. Apel Przewodniczącego Rady Głównej Instytutów Badawczych do ministra zdrowia $z 14$ października 2015 roku w sprawie zaniechania wydzielania oddziału w Gliwicach ze struktur Centrum Onkologii - Instytutu im. Marii Skłodowskiej-Curie.

8. Apel Prezesa Polskiej Unii Onkologii do ministra zdrowia $z 2$ listopada 2015 roku o wstrzymanie działań zmierzających do podziału Centrum Onkologii - Instytutu im. Marii Skłodowskiej-Curie i wydzielenia oddziału w Gliwicach.

9. Pismo ministra finansów z 20 października 2015 roku skierowane do Stałego Komitetu Rady Ministrów w ramach konsultacji publicznych projektu rozporządzenia Rady Ministrów w sprawie połączenia Centrum Onkologii - Instytutu im. Marii Skłodowskiej-Curie oraz Instytutu Hematologii i Transfuzjologii.

10. Relacja $z$ wystąpienia ministra zdrowia Mariana Zembali w trakcie nadzwyczajnego posiedzenia Rady Naukowej Centrum Onkologii - Instytutu im. Marii Skłodowskiej-Curie w dniu 4 listopada 2015 roku. 